\title{
MMP-9 as a potential biomarker for carcinoma of oral cavity: a study in eastern India
}

\author{
D. P. NANDA ${ }^{1}$, K. DUTTA 2 , K. K. GANGULY2 2 , S. HAJRA ${ }^{3}$, S. S. MANDAL ${ }^{4}$, J. BISWAS ${ }^{1}$, D. SINHA $2, *$ \\ ${ }^{1}$ Surgical Oncology, ${ }^{2}$ Receptor Biology and Tumor Metastasis, ${ }^{3}$ Pathology and Biochemistry, ${ }^{4}$ Epidemiology and Biostatistics, Chittaranjan National \\ Cancer Institute, 37, S. P. Mukherjee Road, Kolkata 700 026, India
}

${ }^{*}$ Correspondence: donasinha2012@gmail.com

\section{Received February 13, 2014 / Accepted April 7, 2014}

\begin{abstract}
Carcinoma of oral cavity have a high risk of recurrence after initial treatment with surgery, radiotherapy, surgery with adjuvant radiotherapy, or radio-chemotherapy.The present study investigated the changes in expression, activity and regulation of matrix metalloproteinases (MMP) -2 and -9 in oral squamous cell carcinoma (OSCC) which might help to ascertain the invasive potential of the tumor .

Tumor tissues and adjacent normal tissues of OSCC patients [N,37; either sex; 20-70 yrs] were subjected to clinico-pathology, histopathology and TNM grading. The enzyme activity and associated signalling was observed with gelatin zymography, immunohistochemistry, ELISA, western blot and semi quantitative reverse transcriptase PCR.

OSCC tissues were observed with elevated MMP-9 activity, enhanced expression of fibronectin (FN), phosphorylated focal adhesion kinase (FAK Try 397), phosphatidyl inositol 3-kinase (PI3K), protein kinase B (AKT) and reduced expression of tissue inhibitor of metalloproteinase- 1(TIMP-1) than the control tissues.

OSCC patients elicited a predominance of MMP-9 activity via up regulated FAK/PI3K/AKT pathway. A routine MMP-9 analysis may ascertain the invasiveness of the tumor and therefore may be professed as a suitable biomarker for metastatic potential of oral cancer.
\end{abstract}

Key words: oral squamous cell carcinoma, MMP-9, zymography, eastern India

In India, oral cancer forms a large group of malignancy representing $30-40 \%$ of all cancers [1]. By the year 2020 cancers of the mouth $(64,525 ; 29.5 \%)$, tongue $(38,052 ; 17.4 \%)$ and larynx $(33,855,15.5 \%)$ will be the major sites of oral cancer [2].

The frequency of oral malignancy varies between Indian states which might be due to regional differences in disease-specific risk factors [3]. The pattern of cancer incidence in rural West Bengal showed that the oral cavity, pharynx, larynx contributed to more than half of the cancers in men and about a quarter in women. Indigenous habits of chewing and smoking seemed to be primarily responsible for their high incidence [4].

Oral squamous cell carcinoma (OSCC) is one of the deadliest forms of oral malignancy which is associated with high morbidity and mortality, resulting from local, regional and distant metastasis [5]. This creates a great concern for scientists and prioritizes the search for suitable biomarker of oral cancer.

Matrix metalloproteinases (MMPs) are the principal mediators for the degradation of extracellular matrix (ECM) components which take place during the invasion and metastasis [6, 7]. MMPs are zinc dependent family of endopeptidases and the gelatinases, MMP-2 (Gelatinase A, $72 \mathrm{KDa}$ ) and MMP-9 (Gelatinase B 92 $\mathrm{KDa}$ ), are the master molecules for the malignant phenotype because of their unique property to degrade type IV collagen, a major component of the basement membrane [8].

The orchestra of signaling molecules associated with MMP regulation is highly complicated. In areas with basement membrane defects the invading carcinoma cells may come in contact with the abundant stromal fibronectin (FN) matrix. The $120 \mathrm{kDa}$ proteolytic fragment of FN can induce the generation of plasmin by cells, leading to the activation of MMPs, which break down extracellular matrix barriers and further degrade FN to release pro-migratory fragments, thus forming a loop $[9,10]$. The receptor ligand interaction of $\mathrm{FN}$ with integrins may switch on the phosphorylation signaling cascade of non receptor tyrosine kinase - focal adhesion kinase (FAK) and phosphatidylinositol 3-kinase (PI3K) pathway [11]. PI3K/ 
protein kinase B (AKT) signal pathway has been found abnormally activated during tumorigenesis and tumor progression $[12,13,14]$. Tissue inhibitors of metalloproteinase(s) (TIMPs) were reported as endogenous inhibitors of the proteolytic activity of activated MMP which formed a 1:1 stoichiometric inhibitory complex with the enzyme [15]. Oral cancer patients have been reported with significantly high pro and active forms of MMP-2, MMP-9 total MMP-2, MMP-9 as well as TIMP-1 and TIMP-2 levels [16].

The age standardized incidence rate of oral cancer in India is 12.6 per 100,000 population [17]. Human studies encompassing the activity and expression of MMPs with respect to progression of oral cancer are largely lacking in eastern India. It has been reported from other parts of India that MMP-2 and MMP-9 gets activated in oral cancer [16] but the precise regulation of the enhanced gelatinase activity is still elusive. Against this background the present study was designed to investigate the clinico-pathological correlation of OSCC with the regulation, expression and activity of gelatinases in oral cancer patients of eastern India.

\section{Materials and methods}

Chemicals. Tris base, Acrylamide, Triton X-100 were purchased from Promega Corporation, Madison, WI; NP40, SDS, Tween-20, bisacrylamide and N,N,N,N'-Tetramethyl-Ethylenediamine (TEMED) were purchased from Amresco, Solon, Ohio; Complete mini EDTA free protease inhibitor cocktail (PI) tablet was purchased from Roche Diagnostics, Mannheim, Germany. All primary antibodies (monoclonal and polyclonal), secondary antibodies and, nitroblue tetrazolium chloride and 5 bromo 4 chloro 3 Indoyl phosphates (NBT/BCIP) were purchased from Santa Cruz Biotechnologies, Santa Cruz, CA. Gelatin sepharose 4B beads was purchased from GE Healthcare Bio-Sciences AB, Uppsala, Sweden. RNAqueous ${ }^{\mathrm{R}}$ - 4PCR (DNA-free ${ }^{\mathrm{TM}}$ RNA isolation for RT-PCR) kit, RETROscript Kit (for RT-PCR) and Super Taq Plus polymerase was purchased from Ambion, Life Technologies, Grand Island, NY. Primers for MMP-9 were synthesized by Integrated DNA Technologies, Inc. (Corallville, IA). Nitro cellulose membranes were purchased from Pall Corporation, Pensacola, FL.

Oral cancer tissue samples. The study was conducted with oral cancer patients who had visited the Chittaranjan National Cancer Institute (CNCI), between 2010 and 2012. A detailed clinical history was obtained regarding age, sex, duration, habits, and any other associated illness. The tissue samples (confined to lip, tongue, hard palate and buccal mucosa) were obtained from oral cancer patients after surgery. The project work was approved by Institutional Ethical Committee and a written informed consent was obtained from the patients for their inclusion in the research project.

Histopathology. The detailed histopathology of the oral cancer tissue samples was done by hospital pathology department. The cytological criteria for malignant lesions included presence of enlarged nuclei, hyperchromatism (increased nucleoproteins), variation in nuclear size and shape (anisokaryosis), presence of prominent and irregular nuclear bodies, increased nucleo-cytoplasmic ratio, multiple prominent irregular nucleoli, abnormal chromatin pattern and distribution and discrepancy at maturation. The histological criteria considered for oral squamous cancer were breakage of basement membrane, formation of intracellular bridge, hyperkeratosis and/parakeratosis/ abnormal keratinization and stromal reaction/diathesis.

TNM grading. The TNM Staging of the OSCC tissue samples was done according to $7^{\text {th }}$ edition of cancer staging handbook by American Joint Committee on Cancer (AJCC) [18]. Detail clinical examination was done to see the size of the tumor and the nodal status.

Protein extraction from tissues. Tissues obtained from the tumor samples as well as their adjacent normal counterparts were homogenized with RIPA buffer containing protease inhibitor. The homogenate was centrifuged at $15000 \mathrm{rpm}$ for $15 \mathrm{mins}$ at $4^{\circ} \mathrm{C}$; supernatant was collected and stored at $-86^{\circ} \mathrm{C}$ till further use. A part of the tissue extract was used for protein estimation using Lowry's method [19].

Zymography. The tissue lysates (protein content: $200 \mu \mathrm{g}$ $/ 10 \mu \mathrm{g} / 1 \mu \mathrm{g}$ ) were shaken with Gelatin sepharose $4 \mathrm{~B}$ beads for 2 hours at $4^{\circ} \mathrm{C}$, washed with Tris-buffered saline with Tween-20 $(0.02 \%)[\mathrm{TBST}]$ and suspended sample buffer [(Tris (1.2M), SDS (1.4M)] for 30 mins at $37^{\circ} \mathrm{C}$. The extract was then subjected to zymography according to Sen et al 2010 [11].

In zymography, the proteins are separated by sodium docedecyl sulphate polyacrylamide gel electrophoresis (SDS PAGE) under nonreducing conditions where the substrate gelatin that is co-polymerized with the acrylamide [20]. During electrophoresis, SDS causes the MMPs to denature and become inactive. The activation of latent MMPs during zymography is believed to involve the "cysteine switch" because the disruption of Cys73 at the pro peptide domain from the zinc molecule at the catalytic domain is caused by SDS. Subsequently the gel is washed with Triton ${ }^{\circ} \mathrm{X}-100$, after which the enzymes partially renature and recover their activity [21]. This is followed with the incubation of the gel in an appropriate activation buffer when the concentrated, renatured MMPs in the gel digests the substrate. Finally the gel is stained with Coomassie Blue, and the MMPs are detected as clear bands against a blue background.

Detection of protein expression with ELISA. The ELISA protocol was done according to Sen et al 2010 [11] with slight modifications. Briefly the wells of microtitre plate were coated with tissue lysate $(10 \mu \mathrm{g})$, blocked with blocking buffer (1\% BSA in PBS) for $1 \mathrm{~h}$ at $37^{\circ} \mathrm{C}$, washed with wash buffer $(0.5 \%$ NP-40 \& $0.5 \%$ BSA dissolved in PBS), incubated with primary antibody - anti-FAK polyclonal antibody/ anti-MMP-9, antiTIMP-1/ anti-FAK, anti-pFAK (Tyr 397), anti- PI3K(p85a), anti- pPI3K (Tyr 508), anti- AKT, anti- pAKT (Thr 308) (1:1000 dilution) at $37^{\circ} \mathrm{C}$ for $1 \mathrm{~h}$ and subsequently with respective horse radish peroxidise conjugated secondary antibody solution ( $1: 1000$ dilution) for $37^{\circ} \mathrm{C}$ for $1 \mathrm{~h}$. Finally substrate 3,3,5,5'-Tetramethylbenzidine (in darkness) was added till 
colour developed. Reaction was stopped with $\mathrm{H}_{2} \mathrm{SO}_{4}(1 \mathrm{M})$ and reading was taken in ELISA plate reader [Infinite M200, TECAN, Mannedrof, Switzerland] at $450 \mathrm{~nm}$.

Western blot analysis. Briefly protein $(50 \mu \mathrm{g})$ obtained from tissue extracts were subjected to SDS-PAGE (7.5\%) and blotted onto nitrocellulose membranes, blocked using $5 \%$ BSA in TBS-T (tris buffered saline with Tween-20; $50 \mathrm{mM}$ Tris, $150 \mathrm{mM}$ Nacl, $0.05 \%$ Tween-20), incubated with anti-FAK polyclonal antibody/ anti-MMP-9, anti-TIMP-1/ anti-FAK, anti-pFAK (Tyr 397), anti- PI3K(p85a), anti- pPI3K (Tyr 508), anti- AKT, anti- pAKT (Thr 308) monoclonal antibodies (1:1000 dilution) for $90 \mathrm{~min}$ at $37^{\circ} \mathrm{C}$, washed with TBS- $\mathrm{T}$ and incubated with respective alkaline phosphatase coupled secondary antibody for $90 \mathrm{~min}$ at $37^{\circ} \mathrm{C}(1: 1,000)$. Bands were visualized with substrate NBT/BCIP.

Semi-quantitative RT-PCR. Tissues immersed in Trizol reagent were isolated for total RNA using RNAqueous -4PCR kit (Ambion, Life Technologies, Grand Island, NY). cDNA was synthesized from $2 \mu \mathrm{g}$ of total RNA using RetroScript kit (Ambion/Applied Biosystem) and amplified by polymerase chain reaction $\left(94^{\circ} \mathrm{C}\right.$ for $30 \mathrm{sec}, 55^{\circ} \mathrm{C}$ for $30 \mathrm{sec}, 72^{\circ} \mathrm{C}$ for 90 sec; $28-30$ cycles) using primers (forward primer sequence 5'- CGCTACCACCTCGAACTTTG-3' and reverse primer sequence 5'-GCCATTCACGTCGTCCTTAT-3'; gene bank accession number: NM 8689.2) designed for MMP-9 gene. Positive control was a constitutively expressed "housekeeping" gene rig/S15, encoding a small ribosomal subunit protein (forward primer sequence 5 '-TTCCGCAAGTTCCACCTACC and reverse primer sequence 5 '-CGGGCCGGCCATGCTTTACG). PCR product was analyzed by electrophoresis on $2 \%$ agarose gel along with a 50 bp DNA ladder and visualized under Gel Documentation System (Bio-Rad, Molecular Image Chemi $\mathrm{Doc}^{\mathrm{TM}}$ XRS+ with Image Lab ${ }^{\mathrm{TM}}$ Software, Hercules, CA).

Quantification of the results. Bands of zymography, western blots and RT-PCR were quantitated using Image J Launcher (version 1.4.3.67).

Immunohistochemistry. Paraffin embedded tissue sections $(5 \mu)$ were deparaffinised, rehydrated, boiled with $10 \mathrm{mM}$ sodium citrate buffer (pH-6) at $100^{\circ} \mathrm{C}$ for $15 \mathrm{~min}$, cooled and treated with $0.3 \%$ hydrogen peroxide for $30 \mathrm{~min}$ to block endogenous peroxidase activity. Tissue sections were incubated with $2 \%$ BSA for $1 \mathrm{hr}$, followed with mouse monoclonal antiMMP-9 (1:500 dilution) for $1 \mathrm{hr}$ and biotinylated secondary antibody (Santa Cruz, CA, USA) for 1.5hr. Sections were then exposed to $\mathrm{ABC}$ reagent (Vector laboratories, CA, USA) for 30 min followed by 3, 3'-diaminobenzidine peroxidase substrate (Pierce, Rockford, USA) for $10 \mathrm{~min}$. Finally sections were counterstained with haematoxylin, dehydrated and observed under 40X magnification of microscope (LEICA DM 1000). For quantification of immunohistochemistry, the total number of cells, from all samples $(\mathrm{N}, 37)$, showing presence of brown stain were compared between tumor and corresponding adjacent non-tumor tissue. In both the cases number of cells counted were kept comparable. A minimum of 10 fields were scanned per slide under 40X magnification.
Statistical analysis. Statistical Analysis was performed with help of Epi Info (TM) 3.5.3. EPI INFO is a trademark of the Centers for Disease Control and Prevention (CDC).

Descriptive statistical analysis was performed to calculate the means with corresponding standard errors (s.e.). Z-test (Standard Normal deviate) was used to test the significant difference between two proportions. Student's t-test was used to test the difference between means. One Way Analysis of variance (ANOVA) followed by Tukey's Test was performed with the help of Critical Difference (CD) or Least Significant Difference (LSD) at $5 \%$ and $1 \%$ level of significance. $\mathrm{p} \leq 0.05$ was taken to be statistically significant.

\section{Results}

Clinico-pathological characteristics. Among the OSCC patients $(\mathrm{N}, 37)$, the oral cavity cancer was 3.6 times more frequent

Table 1. Clinico pathological parameters of the oral cancer patients

\begin{tabular}{|c|c|c|}
\hline Parameters & Total No. & Percentage \\
\hline 1. No. of oral cancer patients & 37 & - \\
\hline \multicolumn{3}{|l|}{ 2. Gender } \\
\hline a) Male & 29 & 78.37 \\
\hline b) Female & 8 & 21.62 \\
\hline \multicolumn{3}{|l|}{ 3. Age } \\
\hline$\geq 50$ yrs (median age: $60 \mathrm{yrs}$ ) & 24 & 64.86 \\
\hline$<50$ yrs (median age: 43.5 yrs) & 13 & 35.13 \\
\hline \multicolumn{3}{|l|}{ 4. Site of tumor } \\
\hline a) Alveolus & 9 & 24.32 \\
\hline b) Cheek & 8 & 21.62 \\
\hline c) Tongue & 6 & 16.21 \\
\hline d) Lip & 4 & 10.81 \\
\hline e) Buccal mucosa & 4 & 10.81 \\
\hline f) Retro molar trigone & 3 & 8.10 \\
\hline g) Lower alveolus and adjoining tongue & 1 & 2.70 \\
\hline h) Maxilla & 1 & 2.70 \\
\hline i) Angle of mouth & 1 & 2.70 \\
\hline \multicolumn{3}{|l|}{ 5. Addiction } \\
\hline a) Yes & 24 & 64.86 \\
\hline b) No & 13 & 35.13 \\
\hline \multicolumn{3}{|l|}{ 6. Addiction in } \\
\hline a) Tobacco & 11 & 45.83 \\
\hline b) Betel and tobacco & 3 & 12.50 \\
\hline c) Betel Nut & 2 & 8.33 \\
\hline d) Others & 8 & 33.33 \\
\hline \multicolumn{3}{|l|}{ 7. Grade of tumor } \\
\hline a) I (Well differentiated) & 25 & 67.56 \\
\hline b) II(Moderately differentiated) & 11 & 29.72 \\
\hline c) III(Poorly differentiated) & 1 & 2.70 \\
\hline \multicolumn{3}{|l|}{ 8. Stage of tumor } \\
\hline a) I & 2 & 5.40 \\
\hline b) II & 7 & 18.91 \\
\hline c) III & 7 & 18.91 \\
\hline d) IV & 21 & 56.75 \\
\hline \multicolumn{3}{|l|}{ 9. Lymph node } \\
\hline a) Positive & 17 & 45.95 \\
\hline b) Negative & 20 & 54.05 \\
\hline
\end{tabular}


in males (78.4\% males vs $21.6 \%$ females; Z-4.88; $\mathrm{p}<0.01)$. The malignancy was 1.84 times prevalent in the older age group $(Z$ $2.55 ; \mathrm{p}<0.05)$. Alveolus and cheek were the most common sites of oral malignancies which were $24.3 \%$ and $21.6 \%$ respectively. Patients who were addicted had 1.84 times greater prevalence of oral cancer than the patients who were not addicted (Z-2.55; $\mathrm{p}<0.05)$. Tobacco seemed to be predominant factor related with the oral cancer which comprised of $45.8 \%$ of the total addicted cases (Z-2.54; $\mathrm{p}<0.05)$. Majority of patients were diagnosed with well differentiated Grade I tumors (67.5\%; Z-3.25; $\mathrm{p}<0.01)$. Advanced stage tumors (Stage IV: 56.8\%; Stage III: 18.9\%) were more prevalent and stage IV tumor was significantly higher

Table 2. TNM grading of the oral cancer patient

\begin{tabular}{|c|c|c|}
\hline Clinical Stage & Case & TNM Stage \\
\hline \multirow{2}{*}{ I } & 1 & $\mathrm{~T}_{1} \mathrm{~N}_{\mathrm{x}} \mathrm{M}_{0}$ \\
\hline & 2 & $\mathrm{~T}_{1} \mathrm{~N}_{0}$ \\
\hline \multirow{7}{*}{ II } & 1 & $\mathrm{~T}_{2} \mathrm{~N}_{0} \mathrm{M}_{0}$ \\
\hline & 2 & $\mathrm{~T}_{2} \mathrm{~N}_{0} \mathrm{M}_{0}$ \\
\hline & 3 & $\mathrm{~T}_{2} \mathrm{~N}_{0} \mathrm{M}_{0}$ \\
\hline & 4 & $\mathrm{~T}_{2} \mathrm{~N}_{0} \mathrm{M}_{0}$ \\
\hline & 5 & $\mathrm{~T}_{2} \mathrm{~N}_{0} \mathrm{M}_{0}$ \\
\hline & 6 & $\mathrm{~T}_{2} \mathrm{~N}_{0} \mathrm{M}_{0}$ \\
\hline & 7 & $\mathrm{~T}_{2} \mathrm{~N}_{0} \mathrm{M}_{0}$ \\
\hline \multirow{7}{*}{ III } & 1 & $\mathrm{~T}_{3} \mathrm{~N}_{0} \mathrm{M}_{0}$ \\
\hline & 2 & $\mathrm{~T}_{3} \mathrm{~N}_{1} \mathrm{M}_{0}$ \\
\hline & 3 & $\mathrm{~T}_{3} \mathrm{~N}_{0} \mathrm{M}_{0}$ \\
\hline & 4 & $\mathrm{~T}_{3} \mathrm{~N}_{0} \mathrm{M}_{0}$ \\
\hline & 5 & $\mathrm{~T}_{3} \mathrm{~N}_{0} \mathrm{M}_{0}$ \\
\hline & 6 & $\mathrm{~T}_{3} \mathrm{~N}_{0} \mathrm{M}_{0}$ \\
\hline & 7 & $\mathrm{~T}_{2} \mathrm{~N}_{1} \mathrm{M}_{0}$ \\
\hline \multirow{7}{*}{ IV } & 1 & $\mathrm{~T}_{4 \mathrm{~A}} \mathrm{~N}_{0} \mathrm{M}_{0}$ \\
\hline & 2 & $\mathrm{~T}_{4 \mathrm{~A}} \mathrm{~N}_{0} \mathrm{M}_{0}$ \\
\hline & 3 & $\mathrm{~T}_{4} \mathrm{~N}_{2 \mathrm{~B}} \mathrm{M}_{0}$ \\
\hline & 4 & $\mathrm{~T}_{4 \mathrm{~B}} \mathrm{~N}_{2} \mathrm{M}_{0}$ \\
\hline & 5 & $\mathrm{~T}_{4 \mathrm{~A}} \mathrm{~N}_{2 \mathrm{~B}} \mathrm{M}_{0}$ \\
\hline & 6 & $\mathrm{~T}_{4 \mathrm{~A}} \mathrm{~N}_{0} \mathrm{M}_{0}$ \\
\hline & 7 & $\mathrm{~T}_{1} \mathrm{~N}_{2} \mathrm{M}_{0}$ \\
\hline \multirow{14}{*}{ IV } & 8 & $\mathrm{~T}_{3} \mathrm{~N}_{2 \mathrm{~B}} \mathrm{M}_{0}$ \\
\hline & 9 & $\mathrm{~T}_{3} \mathrm{~N}_{2 / 4} \mathrm{M}_{0}$ \\
\hline & 10 & $\mathrm{~T}_{1} \mathrm{~N}_{2} \mathrm{M}_{0}$ \\
\hline & 11 & $\mathrm{~T}_{4 \mathrm{~A}} \mathrm{~N}_{0} \mathrm{M}_{0}$ \\
\hline & 12 & $\mathrm{~T}_{3} \mathrm{~N}_{1}$ \\
\hline & 13 & $\mathrm{~T}_{4 \mathrm{~A}} \mathrm{~N}_{2 \mathrm{~B}} \mathrm{M}_{0}$ \\
\hline & 14 & $\mathrm{~T}_{4 \mathrm{~A}} \mathrm{~N}_{0} \mathrm{M}_{0}$ \\
\hline & 15 & $\mathrm{~T}_{4} \mathrm{~N}_{2} \mathrm{M}_{0}$ \\
\hline & 16 & $\mathrm{~T}_{4} \mathrm{~N}_{2} \mathrm{M}_{0}$ \\
\hline & 17 & $\mathrm{~T}_{1} \mathrm{~N}_{2 \mathrm{~B}} \mathrm{M}_{0}$ \\
\hline & 18 & $\mathrm{~T}_{4 \mathrm{~A}} \mathrm{~N}_{0} \mathrm{M}_{0}$ \\
\hline & 19 & $\mathrm{~T}_{2} \mathrm{~N}_{2} \mathrm{M}_{0}$ \\
\hline & 20 & $\mathrm{~T}_{2} \mathrm{~N}_{2}$ \\
\hline & 21 & $\mathrm{~T}_{4} \mathrm{~N}_{1} \mathrm{M}_{0}$ \\
\hline
\end{tabular}

Table 3a. Comparison of pro MMP-9 activity between oral cancer tissue samples and adjacent normal tissues

\begin{tabular}{|c|c|c|c|c|}
\hline \multirow[t]{2}{*}{ Clinical Stage } & \multirow[t]{2}{*}{ Cases } & \multicolumn{2}{|c|}{ Band intensities of Pro MMP9 } & \multirow[t]{2}{*}{ Fold Change } \\
\hline & & $\mathbf{N}$ & $\mathbf{T}$ & \\
\hline I & 1 & 12.83 & 82.67 & $6.44 \uparrow$ \\
\hline \multirow{8}{*}{ II } & 2 & 3.85 & 16.10 & $4.18 \uparrow$ \\
\hline & 1 & 18.65 & 95.10 & $5.09 \uparrow$ \\
\hline & 2 & 51.94 & 97.68 & $1.88 \uparrow$ \\
\hline & 3 & 139.98 & 231.03 & $1.65 \uparrow$ \\
\hline & 4 & 48.81 & 75.77 & $1.55 \uparrow$ \\
\hline & 5 & 42.53 & 95.70 & $2.25 \uparrow$ \\
\hline & 6 & 34.05 & 45.52 & $1.33 \uparrow$ \\
\hline & 7 & 33.33 & 102.83 & $3.08 \uparrow$ \\
\hline \multirow{7}{*}{ III } & 1 & 143.83 & 205.06 & $1.42 \uparrow$ \\
\hline & 2 & 17.68 & 93.13 & $5.26 \uparrow$ \\
\hline & 3 & 7.02 & 143.84 & $20.49 \uparrow$ \\
\hline & 4 & 51.52 & 167.53 & $3.25 \uparrow$ \\
\hline & 5 & 110.48 & 236.32 & $2.13 \uparrow$ \\
\hline & 6 & 6.03 & 44.69 & $7.41 \uparrow$ \\
\hline & 7 & 46.86 & 87.39 & $1.86 \uparrow$ \\
\hline \multirow{21}{*}{ IV } & 1 & 26.66 & 192.18 & $7.20 \uparrow$ \\
\hline & 2 & 7.95 & 72.51 & $9.12 \uparrow$ \\
\hline & 3 & 13.04 & 32.75 & $2.51 \uparrow$ \\
\hline & 4 & 59.07 & 184.29 & $3.11 \uparrow$ \\
\hline & 5 & 81.37 & 107.78 & $1.32 \uparrow$ \\
\hline & 6 & 127.32 & 191.99 & $1.50 \uparrow$ \\
\hline & 7 & 70.24 & 91.77 & $1.30 \uparrow$ \\
\hline & 8 & 24.83 & 129.73 & $5.22 \uparrow$ \\
\hline & 9 & 18.87 & 131.89 & $6.98 \uparrow$ \\
\hline & 10 & 192.10 & 231.13 & $1.20 \uparrow$ \\
\hline & 11 & 161.96 & 225.20 & $1.39 \uparrow$ \\
\hline & 12 & 38.88 & 40.68 & $1.04 \uparrow$ \\
\hline & 13 & 22.69 & 157.83 & $6.95 \uparrow$ \\
\hline & 14 & 105.94 & 152.80 & $1.44 \uparrow$ \\
\hline & 15 & 75.58 & 211.99 & $2.80 \uparrow$ \\
\hline & 16 & 43.76 & 10.75 & $4.07 \downarrow$ \\
\hline & 17 & 6.44 & 47.15 & $7.32 \uparrow$ \\
\hline & 18 & 36.14 & 130.66 & $3.61 \uparrow$ \\
\hline & 19 & 42.64 & 80.14 & $1.87 \uparrow$ \\
\hline & 20 & 29.99 & 59.21 & $1.97 \uparrow$ \\
\hline & 21 & 38.60 & 23.07 & $1.67 \downarrow$ \\
\hline
\end{tabular}

Table 3b. Comparison of pro MMP-9 activity between oral cancer tissue samples and adjacent normal tissues.

\begin{tabular}{lccc}
\hline \multirow{2}{*}{ Clinical Stage } & \multicolumn{2}{c}{ Band intensities of Pro MMP9 } & \multirow{2}{*}{ p-values } \\
\cline { 2 - 3 } & N $($ Mean \pm S.E $)$ & T $($ Mean \pm S.E $)$ & \\
\hline I $(n=2)$ & $8.34 \pm 4.49$ & $49.38 \pm 33.28$ & $<0.01$ \\
II $(n=7)$ & $52.75 \pm 15.13$ & $106.23 \pm 22.09$ & $<0.01$ \\
III $(n=7)$ & $54.77 \pm 20.20$ & $139.71 \pm 25.97$ & $<0.01$ \\
IV $(n=21)$ & $58.28 \pm 11.06$ & $119.31 \pm 15.29$ & $<0.01$ \\
\hline
\end{tabular}


(Z-3.35; $\mathrm{p}<0.01)$. Lymph node metastasis did not exhibit any significant pattern as both positive and negative lymph nodes showed an equal distribution pattern (positive $45.6 \%$ vs negative 54.1\%; Z-0.69; p>0.05). The detailed Clinico-pathological information of the OSCC patients has been tabulated in Table 1 and the TNM staging in Table 2.

Variation in MMP-9 activity along with the clinical stage of the OSCC patients. All the tumor samples irrespective of the clinical stage were observed with a significant elevated activity of MMP-9 than the adjacent normal tissues (Fig.1a) as evidenced from gelatine zymography. MMP-2 activity was not prominent in all the samples and therefore investigation was further concentrated on MMP-9 expression and activity. The activity of MMP-9 was so high in some tumors that it could be detected even with a minimum protein loading of $10 \mu \mathrm{g}$ and $1 \mu \mathrm{g}$ (Fig. $1 \mathrm{~b}$ ).

The detailed account of the pro MMP-9 and active MMP-9 activity in all the tumor samples and their adjacent normal counterparts along with their respective clinical stages and the fold change have been depicted in Table $3 \mathrm{a}$ and $4 \mathrm{a}$ respectively. All the tumor tissues in the stages I, II, III had higher pro MMP-9 (92 KD) and active MMP-9 (84KD) activity than the normal counter parts. The activity of MMP-9 showed variation in fold change both within the same clinical stage as well in between the clinical stages. In stage IV, $90.5 \%$ of the samples ( 19 out of 21 ; Table $3 a$ ) and $100 \%$ samples (21 out of 21 ; Table $3 \mathrm{~b}$ ) were observed with elevated pro MMP-9 and active MMP-9 activity respectively. However $9.5 \%$ of the samples (2 out of 21; Table 3a) showed reduced pro MMP-9 activity but elevated levels of active MMP-9 (Table 4a) which accounted for an aggressive form of MMP-9 activity.

The mean values of pro MMP-9 and active MMP-9 in tumor samples $(\mathrm{T})$ was significantly higher than their adjacent normal counterparts $(\mathrm{N})$ for each stage $(\mathrm{p}<0.01$; Table $3 \mathrm{~b}$, $4 \mathrm{~b})$. The mean of both $\mathrm{N}$ and $\mathrm{T}$ was significantly lower for Stage-I than advanced stages ( $p<0.01$; Table $3 b, 4 b)$. ANOVA

a.

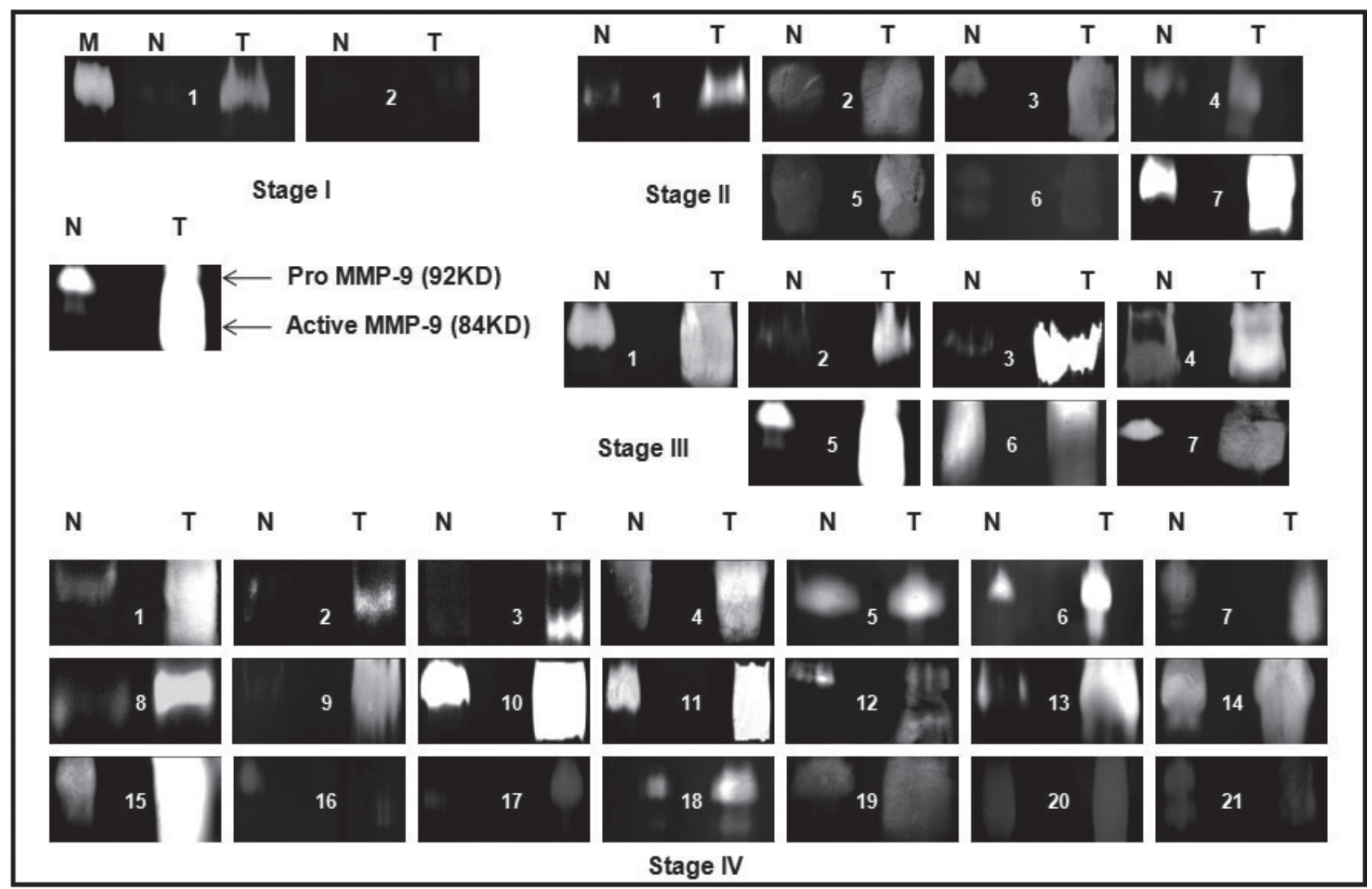

b.

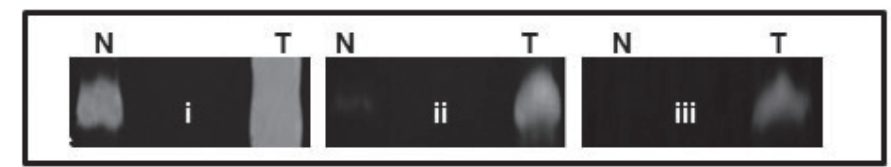

Figure 1. Activity of MMP-9 as assessed by gelatin zymography in OSCC tumor tissues (T), adjacent normal counterparts (N) and marker (M). The elevated activity of pro MMP-9 $(92 \mathrm{KD})$ and active MMP-9 $(84 \mathrm{KD})$ in $\mathrm{T}$ in comparison to $\mathrm{N}$ have been depicted in different clinical stages of OSCC (a). The comparative zymogram in the same tissue samples with varying amount of protein $200 \mu \mathrm{g}(\mathrm{i}), 10 \mu \mathrm{g}$ (ii) and $1 \mu \mathrm{g}$ (iii) depicting MMP-9 activity (b). 
showed significant difference between of $\mathrm{N}$ and $\mathrm{T}$ values of pro MMP- 9 values $\left(\mathrm{F}_{1,72}=21.53 ; \mathrm{p}<0.01\right)$ as well as that of active MMP-9 $\left(\mathrm{F}_{1,72}=36.11 ; \mathrm{p}<0.01\right)$. Even according to the Critical Difference the mean of $\mathrm{T}$ was significantly higher than $\mathrm{N}$ in both the cases of pro and active MMP-9 $(\mathrm{p}<0.01)$.

Protein profile and gene profile of MMP-9 expression. The expression of the MMP-9 was further validated with IHC, western blot and ELISA. Immunohistochemical observations showed pronounced stromal localization of MMP-9 in OSCC tumor samples (T) in comparison to the adjacent normal counterparts $(\mathrm{N})$ irrespective of the clinical stage (Fig. 2a).

MMP-9 expression was found to be significantly higher in OSCC tumor samples $\left({ }^{*} \mathrm{p}<0.05\right)$ as assessed by ELISA (Fig. a.

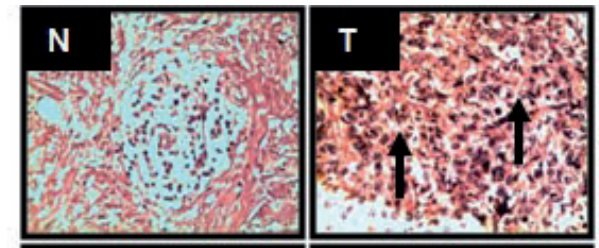

N

c.

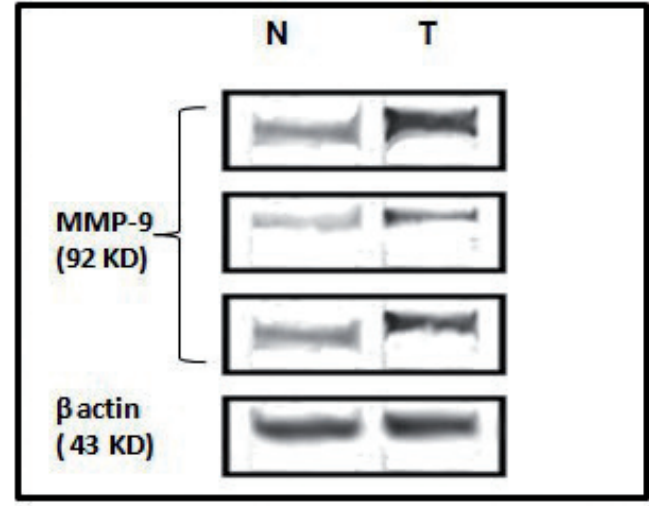

e.

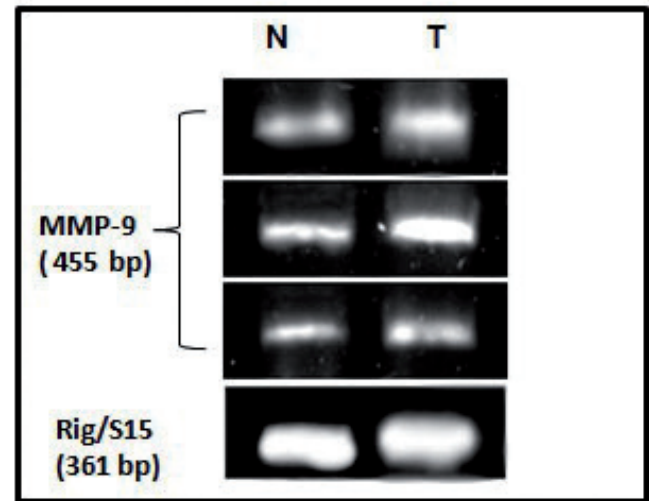

b.

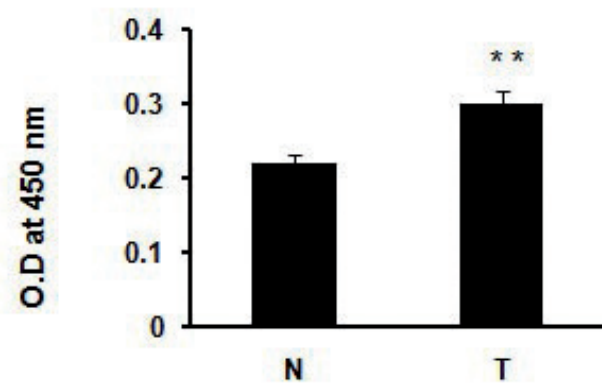

d.

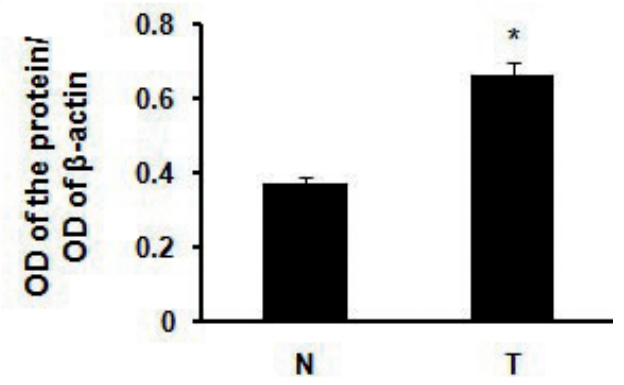

f.

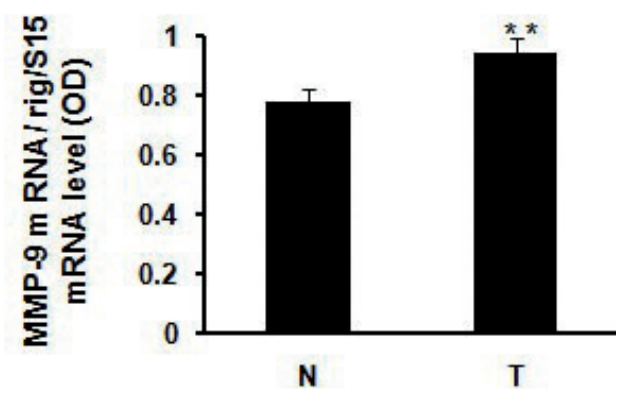

Figure 2. Expression of MMP-9 in OSCC tumor tissues (T), adjacent normal counterparts (N). IHC showing dispersed tumor cells with hyperchromatic nuclei, prominent nucleoli, cytoplasmic keratinization and stroma with strong expression of MMP-9, on the other hand normal fibrocollagenase adjoining tissue showing lymphocyte infiltration and insignificant MMP-9 expression (a); ELISA revealing that mean optical density of MMP-9 at $450 \mathrm{~nm}$ was significantly elevated for $\mathrm{T}\left({ }^{* *} \mathbf{p}<0.05\right)$ than $\mathrm{N}(\mathrm{b})$; representative western blots showing pronounced expression of MMP-9 in T compared to $\mathrm{N}(\mathrm{c})$; Mean band intensities of western blots analyses exhibiting significantly higher expression of MMP- 9 in $T\left({ }^{*}\right.$ p $\left.<0.01\right)$ compared to N (d); RT-PCR exhibiting prominent expression of MMP-9 in T compared to $\mathrm{N}(\mathrm{d})$; Mean band intensities of mRNA eliciting higher expression of MMP-9 in T $\left({ }^{\star} \mathrm{p}<0.05\right)$ compared to N (e) [ IHC observations were made under 400X magnification; Band intensities calculated with Image J Launcher (version 1.4.3.67); the mean band densities were represented as the ratio of the mean optical density $(O D)$ of the specific protein and the mean OD of the loading control $\beta$ actin]; Mean band intensities of RT-PCR analyses exhibiting significantly higher expression of MMP-9 in $T\left({ }^{* *} \mathbf{p}<0.05\right)$ compared to $\mathrm{N}(\mathrm{f})$. 
$2 \mathrm{~b})$. The western blot analyses showed elevated expression of MMP-9 (Fig. 2c) and significantly higher mean band instensity in tumor samples $\left({ }^{*} \mathrm{p}<0.01\right)$ (Fig. $2 \mathrm{~d}$ ). The mRNA profile also revealed enhanced transactivation of MMP-9 in tumor samples (Fig. 2e) and higher mean band intensities of MMP-9 mRNA in OSCC tumor tissues were significantly higher $\left({ }^{*} \mathrm{p}<0.05\right)$ than normal (Fig. 2f).

Signaling network associated with MMP-9 expression. Investigation of the signaling crosstalk related with up regulated MMP-9 expression revealed enhanced expression of FN, FAK, pFAK (Tyr 397), PI3K (p85a), pPI3K (Tyr 508), AKT, pAKT (Thr 308) and the reduced expression of TIMP-1 in the OSCC tumor tissues compared normal counterparts (Fig. $3 a ; p<0.01$ ) as assessed with ELISA. Western blot analyses and corresponding band intensities (calculated with Image J software) further validated the similar trend of elevated expression of FN, FAK, pFAK (Tyr 397), PI3K(p85a), pPI3K (Tyr 508), AKT, pAKT (Thr 308) and the reduced expression of TIMP- 1 in the oral cancer tumor tissues compared normal counterparts [Fig. $3 \mathrm{~b}, 3 \mathrm{c}\left({ }^{*} \mathrm{p}<0.05\right)$ respectively]. The activity of pFAK (Tyr 397) [Representative image Fig. 4a and 4b] and pAKT (Thr 308) [Representative image, Fig. $4 \mathrm{c}$ and $4 \mathrm{~d}$ ] were further reconfirmed with IHC in tumor tissues and adjacent normal tissues. The quantitative IHC analysis also revealed higher expression pFAK ( $57 \pm 8$ vs $7 \pm 3$; $\mathrm{p}<0.001)$ and $\mathrm{pAKT}(23+3$ vs $5 \pm 2$; $\mathrm{p}<0.001)$ in tumor sections than adjacent non-tumor sections.

\section{Discussion}

Indian statistics of cancer mortality was estimated to a frequency of $71 \%$ in people aged 30-69 years for whom oral cancer was the most prevalent fatal form of malignancy which accounted for $22.9 \%$ deaths [22].

The present study was conducted in a regional cancer centre of eastern India which caters a majority of eastern Indian population. The pattern of male dominance (70\%) in the OSCC cases may be a reflection of gender differences in the lifestyle and behavioural patterns associated with oral cancer. Majority of the patients (about $65 \%$ ) belonged to the age group of 50 years or above which is in congruence with other reports which proposed an increasing trend of OSCC with age [23].

The OSCC patients were observed with a prevalence of carcinoma in cheek and alveolus which might be attributed to the addiction of tobacco and especially smokeless tobacco. In eastern India, different forms of tobacco addictions are popular such as khaini, gudakhu, snuff, bidi, paan and gutkha. A recent study reported that males with the habit of smokeless tobacco or mixed habit had the highest risk for developing OSCC while in females, it was associated with addiction of chewing processed areca nut [24].

Detailed clinical staging depicted that more than $50 \%$ of the patients came with advanced stage of the tumor (Stage IV) which might have been due to poor socio-economic conditions, inadequate access to trained professionals and limited health services.
Table 4a: Comparison of active MMP-9 activity between oral cancer tissue samples and adjacent normal tissues

\begin{tabular}{|c|c|c|c|c|}
\hline \multirow[t]{2}{*}{ Stage } & \multirow[t]{2}{*}{ Cases } & \multicolumn{2}{|c|}{ Band intensities of active MMP9 } & \multirow[t]{2}{*}{ Fold Change } \\
\hline & & $\mathbf{N}$ & $T$ & \\
\hline I & 1 & 9.44 & 15.47 & $1.63 \uparrow$ \\
\hline \multirow{8}{*}{ II } & 2 & 3.23 & 3.23 & No Change \\
\hline & 1 & 1.43 & 2.51 & $1.75 \uparrow$ \\
\hline & 2 & 7.69 & 85.09 & $11.06 \uparrow$ \\
\hline & 3 & 0.92 & 191.53 & $208.18 \uparrow$ \\
\hline & 4 & 11.78 & 52.67 & $4.47 \uparrow$ \\
\hline & 5 & 40.67 & 91.93 & $2.26 \uparrow$ \\
\hline & 6 & 24.87 & 41.44 & $1.66 \uparrow$ \\
\hline & 7 & 0.99 & 87.68 & $88.29 \uparrow$ \\
\hline \multirow{7}{*}{ III } & 1 & 7.52 & 190.06 & $25.27 \uparrow$ \\
\hline & 2 & 1.17 & 1.40 & $1.19 \uparrow$ \\
\hline & 3 & 7.02 & 143.84 & $20.49 \uparrow$ \\
\hline & 4 & 16.12 & 23.90 & $1.48 \uparrow$ \\
\hline & 5 & 70.89 & 175.76 & $2.47 \uparrow$ \\
\hline & 6 & 9.63 & 238.12 & $24.72 \uparrow$ \\
\hline & 7 & 0.31 & 2.29 & $7.38 \uparrow$ \\
\hline \multirow{21}{*}{ IV } & 1 & 3.10 & 194.98 & $62.89 \uparrow$ \\
\hline & 2 & 4.72 & 5.45 & $1.15 \uparrow$ \\
\hline & 3 & 13.36 & 165.75 & $12.40 \uparrow$ \\
\hline & 4 & 11.41 & 107.80 & $9.44 \uparrow$ \\
\hline & 5 & 9.15 & 29.39 & $3.21 \uparrow$ \\
\hline & 6 & 52.08 & 151.18 & $2.90 \uparrow$ \\
\hline & 7 & 10.78 & 116.22 & $10.78 \uparrow$ \\
\hline & 8 & 12.53 & 19.79 & $1.57 \uparrow$ \\
\hline & 9 & 18.14 & 72.98 & $4.02 \uparrow$ \\
\hline & 10 & 14.63 & 234.32 & $16.01 \uparrow$ \\
\hline & 11 & 4.33 & 237.85 & $54.93 \uparrow$ \\
\hline & 12 & 3.94 & 59.82 & $15.18 \uparrow$ \\
\hline & 13 & 1.27 & 84.07 & $66.19 \uparrow$ \\
\hline & 14 & 42.71 & 106.34 & $2.48 \uparrow$ \\
\hline & 15 & 18.74 & 190.42 & $10.16 \uparrow$ \\
\hline & 16 & 12.46 & 20.31 & $1.63 \uparrow$ \\
\hline & 17 & 0.03 & 2.33 & $77.66 \uparrow$ \\
\hline & 18 & 11.81 & 51.66 & $4.37 \uparrow$ \\
\hline & 19 & 4.52 & 47.49 & $10.50 \uparrow$ \\
\hline & 20 & 20.43 & 56.75 & $2.77 \uparrow$ \\
\hline & 21 & 25.81 & 26.80 & $1.03 \uparrow$ \\
\hline
\end{tabular}

Table $4 \mathrm{~b}$. Comparison of active MMP- 9 activity between oral cancer tissue samples and adjacent normal tissues

\begin{tabular}{llll}
\hline Clinical Stage & \multicolumn{2}{l}{$\begin{array}{l}\text { Band intensities of } \\
\text { active MMP-9 }\end{array}$} & p-values \\
\cline { 2 - 3 } & N (Mean \pm S.E $)$ & T $($ Mean \pm S.E $)$ & \\
\hline I $(\mathrm{n}=2)$ & $6.33 \pm 3.11$ & $9.35 \pm 6.12$ & $<0.01$ \\
II $(\mathrm{n}=7)$ & $12.62 \pm 5.68$ & $78.97 \pm 22.31$ & $<0.01$ \\
III $(\mathrm{n}=7)$ & $16.09 \pm 9.35$ & $110.76 \pm 37.51$ & $<0.01$ \\
IV $(\mathrm{n}=21)$ & $14.14 \pm 2.85$ & $94.31 \pm 16.34$ & $<0.01$ \\
\hline
\end{tabular}


Matrix metalloproteinases are a family of zinc dependent endopeptidases that are capable of degrading most components of the ECM [25]. MMP-9 cleaves basement membrane collagen types IV and V, different types of gelatin as well as FN [26] and is the major MMP associated with malignant cancers. MMP-2 and MMP-9 were found significantly elevated in expression and activity in OSCC patients than control in a study population of western India [16]. The present findings indicate a consistent enhanced expression and activity of MMP-9 in OSCC tissues than adjacent control tissues but the same was not applicable for MMP-2. MMP-2 was found with elevated activity in some cases (data not shown) but this was not persistent for all the tumor samples. The difference in expression and activity of MMP-2 in eastern and western India may have been due to the geographical variations which suggest involvement of genetic polymorphisms in MMP-2 [27]. The activity of MMP-9 also revealed a wide range of individual variation which might be attributed to the genetic polymorphisms in the MMP-9 gene [28].

Over expression is not sufficient for the in vivo action of gelatinases, since MMPs are secreted as inactive zymogens (pro MMP) and activated in the extracellular milieu. It was interesting to find that majority the OSCC tumor tissues were observed with an increase in pro MMP-9 but some samples of stage IV showed a decrease in pro MMP9 activity and high active MMP-9 activity than normal counterparts. This might have been due to conversion of the inactive zymogen, pro MMP-9 to active MMP-9. Pro MMP-9 has been known to be activated by active stromelysins MMP-3, MMP-10 and active collagenase-3, MMP-13.

a.

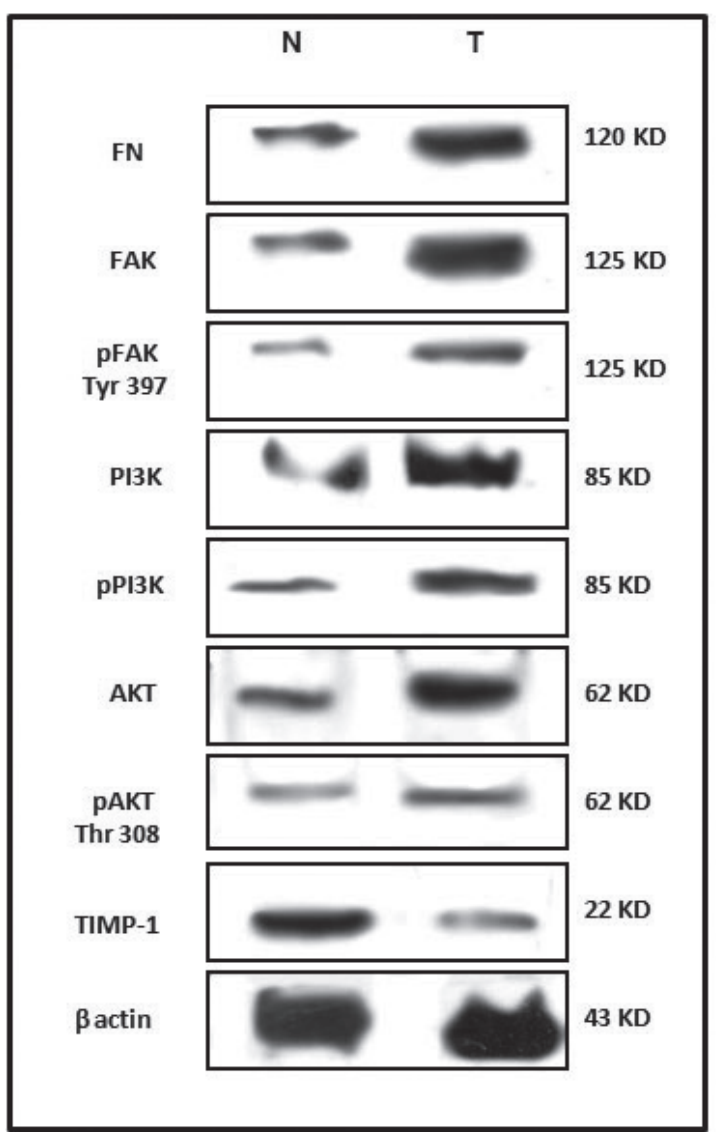

b.

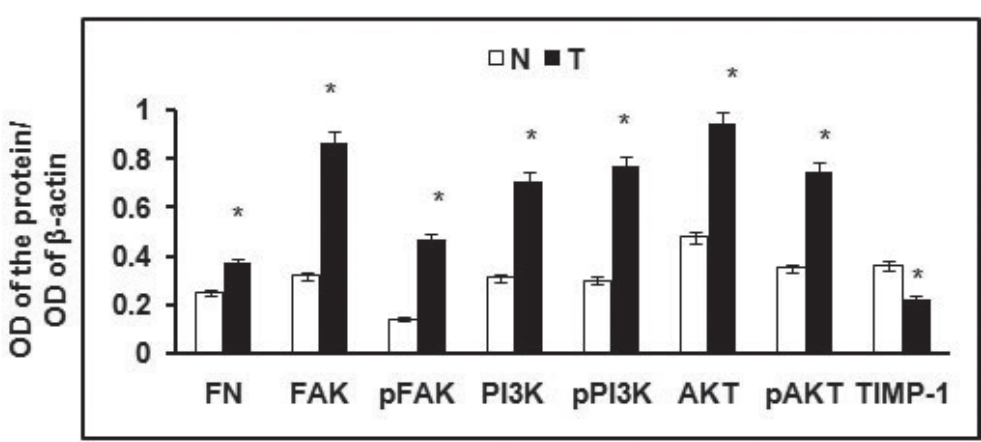

c.

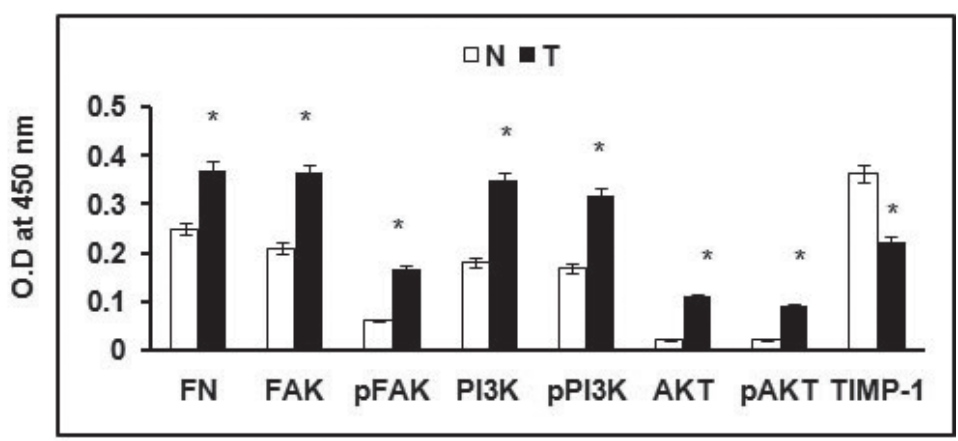

Figure 3. Signaling associated with regulation of MMP-9 in OSCC patients. Representative immunoblots of OSCC patients depicting prominent expression of FN, FAK, FAK Tyr397, PI3K, pPI3K, AKT and pAKT Thr 308 in tumor samples in comparison to adjacent normal tissue samples where as the expression of TIMP-1 was found reduced in the tumor tissues than the respective normal tissues (a); Similar expression of protein profile was observed with mean band intensities of immunoblot where FN, FAK, FAK Tyr397, PI3K, pPI3K, AKT and pAKT Thr 308 showed significant increase and TIMP-1 showed reduced intensity $\left({ }^{\star} \mathbf{p}<0.05\right)$ in OSCC tumor samples than the associated normal tissues $(b)$; ELISA results were observed with similar pattern of protein expression where mean OD of FN, FAK, FAK Tyr397, PI3K, pPI3K, AKT and pAKT Thr 308 showed significant increase and TIMP-1 showed decreased OD $\left({ }^{*} \mathbf{p}<0.05\right)$ at $450 \mathrm{~nm}$ in OSCC tumor samples than the associated normal tissues (c) [ Band intensities calculated with Image J Launcher (version 1.4.3.67); the mean band densities were represented as the ratio of the mean optical density (OD) of the specific protein and the mean OD of the loading control $\beta$ actin]. 
In OSCC cell lines pro MMP-9 was observed to be activated with MMP-10 [29].Thus, intermolecular activation by these active enzymes may be a possible mechanism for pro MMP9 activation in cancer tissues.

Integrin receptor binding to ECM proteins triggers a downstream intracellular signaling cascade involved in cell migration. The ECM protein, FN, has been shown to bind with classical integrin receptor $\alpha 5 \beta 1$ and aggrevated MMP-
9 expression in laryngeal carcinoma [11]. A feedback loop was proposed in OSCC invasion where cells expressing av $\beta 6$ integrin were more motile towards the $120 \mathrm{kDa}$ cell-binding fragment of FN and secreted enhanced levels of MMPs that were capable of generating further $120 \mathrm{KD}$ fragment [30]. In congruence to the above studies the present findings reflected an enhanced expression of FN, $120 \mathrm{KD}$ fragment in the OSCC tumor samples with high MMP-9 activity.
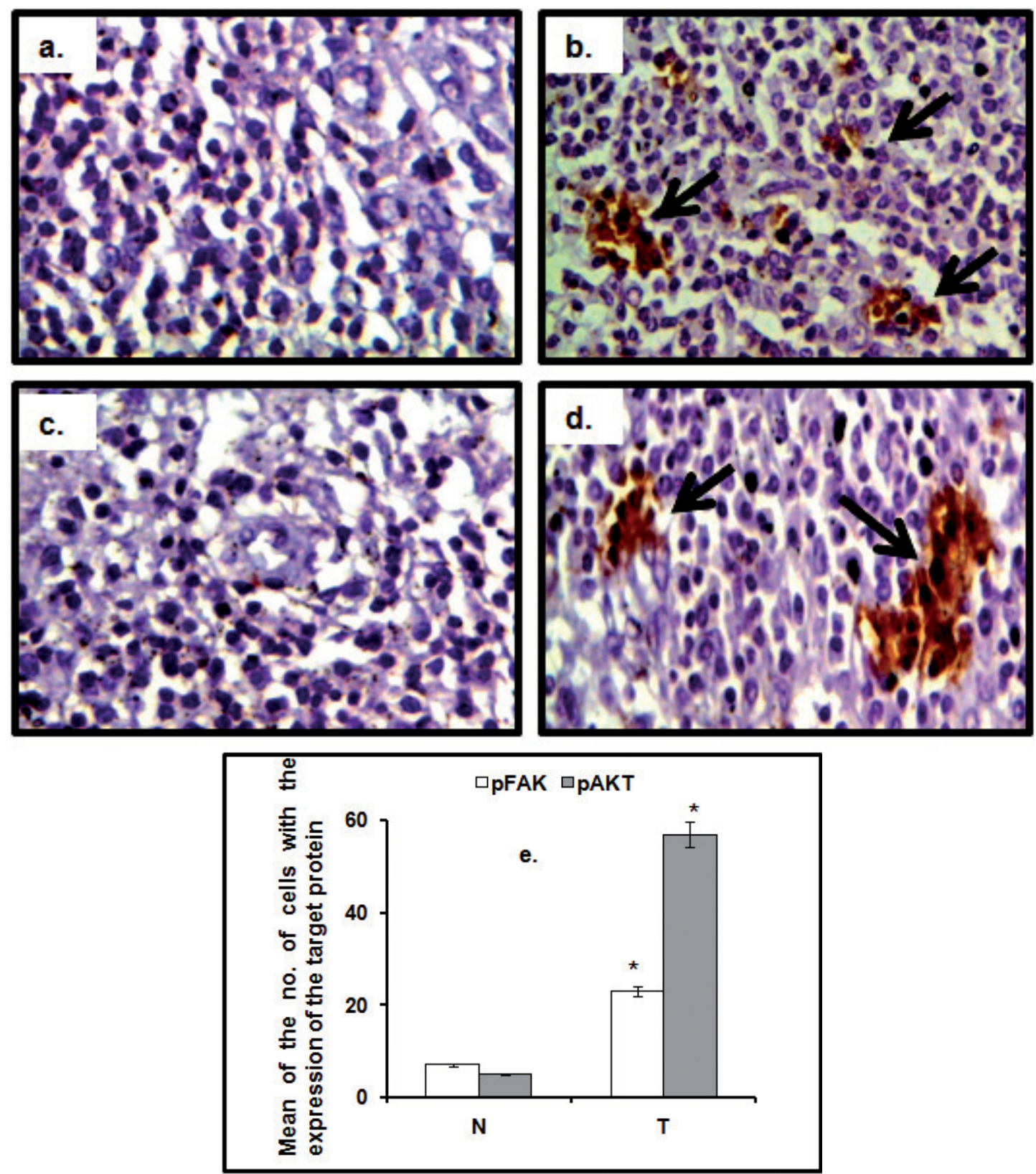

Figure 4. The activity of the pFAK (Tyr397) and pAKT (Thr 308) as assessed with IHC. Representative images are showing: Adjacent normal tissue with negligible localization of pFAK (Tyr397) (a); Enhanced activity of pFAK (Tyr397) in OSCC tissues (b); adjacent normal tissue with negligible localization of pAKT ( Thr 308) (c); Enhanced activity of pAKT ( Thr 308) in OSCC tissues (d); Quantitative analysis of IHC revealing higher mean values of the number of cells with expression of $\mathrm{pFAK}$ and $\mathrm{pAKT}$ in tumor tissues compared to adjacent normal tissues $\left({ }^{*} \mathrm{p}<0.001\right.$ as assessed by Student's $\mathrm{t}$ test). 
Subsequent to binding of FN with integrin, FAK is activated by autophosphorylation at Tyr 397. This event triggers proteins like the SH2 domain of $\mathrm{p} 85$ subunit of PI3K to interact with FAK at Tyr 397 [31]. In accordance with FN mediated FAK signaling the OSCC tumor tissues were observed with increased phosphorylation of FAK Tyr 397. FN was found associated with increased non small cell lung carcinoma cell growth by PI-3K activation [32]. PI3K/AKT pathway has been abnormally activated and closely associated with tumorigenesis and tumor progression [12]. AKT, a key regulator of cell survival and apoptosis has been associated with increased phosphorylation in a variety of cancers [33]. In the present context PI3K expression and phosphorylation at Tyr 508 was found up regulated in the oral cancer tissues which might have been influenced by increased phosphorylation of FAK Tyr 397. Phosphorylation of PI3K Tyr 508 in turn might have phosphorylated AKT at Thr 308, in the OSCC tumor tissues.

Moreover PI-3K signaling pathway was observed to be necessary for the FN-dependant activation of MMP-9 secretion and gene expression [11,34]. A number of recent reports have proposed the involvement of PI3K/AKT pathway in up regulation of MMP-9 expression [11,35, 36, 37]. In accordance with the above studies the OSCC tumor samples reflected the FN mediated phosphorylation of FAK Tyr 397 which in turn increased the expression and activity of MMP-9 via phosphorylation of the PI3K-AKT pathway.

Enhanced activity of MMPs results from the over expression or from reduced expression of TIMPs, and vice versa [38]. Pro-MMP-9 complexes with TIMP-1, and both TIMP- 1 and TIMP-2 can complex with active MMP-9 [39]. In the present study the OSCC tissues were evidenced with reduced expression of TIMP1 which might have contributed towards the radical increase in MMP-9 activity.

The study encompasses certain limitations like the activity of MMP-9 could not be correlated with progression of the clinical stage of the oral cavity tumor. This was firstly due to small sample and unequal sample size of each clinical stage and secondly due to wide variation in activity of MMP-9 within the same clinical stage. Moreover the prognostic value of MMP-9 could not be ascertained as more than $50 \%$ of the patients discontinued the hospital visit after two years. In spite of the shortcomings the study indicates towards importance of the MMP-9 as a predictive biomarker in OSCC patients. There are very few reports on OSCC cases in eastern India and these findings would add on to the existing knowledge of the role of MMP-9 in carcinoma of oral cavity. The mean value of MMP-9 activity was significantly lower $(p<0.01)$ for OSCC tumors in Stage I than tumors in Stage II, III and IV. This conclusively propagates that MMP-9 activity increase with the aggressiveness of the tumors in the advanced stages. Moreover the findings have brought forward the involvement of the signaling axis including FN, pFAK, pPI3K and pAKT in up regulating the activity and expression of MMP-9 in the OSCC patients. A routine analysis of MMP- 9 with the rapid and cost effective technique of gelatin zymography would certainly help the clinicians to have a better idea about the invasive potential of the oral cavity tumor.

\section{References}

[1] PARKIN DM, BRAY F, FERLAY J, PISANI P. Global cancer statistics 2002. CA Cancer J Clin 2005; 55: 74-108. http:// dx.doi.org/10.3322/canjclin.55.2.74

[2] TAKIAR R, NADAYIL D, NANDAKUMAR A. Projections of Number of Cancer Cases in India (2010-2020) by Cancer Groups. Asian Pacific J Cancer Prev 2010; 11: 1045-1049.

[3] MANOHARAN N, TYAGI BB, RAINA V. Cancer incidences in rural Delhi-2004-05. Asian Pacific J Cancer Prev 2010; 11: 73-78.

[4] KARMAKAR R, BANDYOPADHYAY A, BARUI G, MAITI PK, BHATTACHARYA A et al. Pattern of cancer occurrence in rural population of West Bengal--a hospital-based study. J Indian Med Assoc 2010; 108: 505-506.

[5] HICKS WL JR, LOREE TR, GARCIA RI, MAAMOUN S, MARSHALL D et al. Squamous cell carcinoma of the floor of the mouth: A 20 year review. Head Neck 1997; 19: 400-405. http://dx.doi.org/10.1002/(SICI)10970347(199708)19:5<400::AID-HED6>3.0.CO;2-3

[6] KESSENBROCK K, PLAKS V \& WERB Z. Matrix metalloproteinases: regulators of the tumor microenviroment. Cell 2010; 141: 52-67. http://dx.doi.org/10.1016/j.cell.2010.03.015

[7] PAGE-MCCAW A, EWALD AJ \& WERB Z. Matrix metalloproteinases and the regulation of tissue remodelling. Nat Rev Mol Cell Biol 2007; 8: 221-233. http://dx.doi.org/10.1038/ $\underline{\text { nrm2 } 2125}$

[8] NELSON AR, FINGLETON B, ROTHENBERG ML, MATRISIAN LM. Matrix metalloproteinases: biologic activity and clinical implications. J Clin Oncol 2000; 18: 1135-1149.

[9] KAPILA YL, KAPILA S, JOHNSON PW. Fibronectin and fibronectin fragments modulate the expression of proteinases and proteinase inhibitors in human periodontal ligament cells. Matrix Biol 1996; 15: 251-261. http://dx.doi.org/10.1016/ $\underline{\text { S0945-053X(96)90116-X }}$

[10] GRANT MB, CABALLERO S, BUSH DM, SPOERRI PE. Fibronectin fragments modulate human retinal capillary cell proliferation and migration. Diabetes 1998; 47: 1335-1340. http://dx.doi.org/10.2337/diab.47.8.1335

[11] SEN T, DUTTA A, MAITY G, CHATTERJEE A. Fibronectin induces matrix metalloproteinase-9 (MMP-9) in human laryngeal carcinoma cells by involving multiple signaling pathways. Biochimie 2010; 92: 1422-34. http://dx.doi.org/10.1016/ j.biochi.2010.07.005

[12] LEVINE DA, BOGOMOLNIY F, YEE CJ, LASH A, BARAKAT RR et al. Frequent mutation of the PIK3CA gene in ovarian and breast cancers. Clin Cancer Res 2005; 11: 2875 -2878. http://dx.doi.org/10.1158/1078-0432.CCR-04-2142

[13] SHIBATA K, KIKKAWA F, NAWA A, THANT AA, NARUSE $\mathrm{K}$ et al. Both focal adhesion kinase and c-Ras are required for the enhanced matrix metalloproteinase 9 secretion by fibronectin in ovarian cancer cells. Cancer Res 1998; 58: 900-903.

[14] QIU Q, YANG M, TSANG B K, GRUSLIN A. EGF-induced trophoblast secretion of MMP-9 and TIMP-1 involves 
activation of both PI3K and MAPK signalling pathways. Reproduction 2004; 128: 355-363. http://dx.doi.org/10.1530/ rep. 1.00234

[15] VISSE R, NAGASE H. Matrix metalloproteinases and tissue inhibitors of metalloproteinases: structure, function, and biochemistry. Circ Res 2003; 92: 827-839. http://dx.doi. org/10.1161/01.RES.0000070112.80711.3D

[16] SINGH RD, HARIDAS N, PATEL JB , SHAH FD, SHUKLA $\mathrm{SN}$ et al. Matrix metalloproteinases and their inhibitors: Correlation with invasion and metastasis in oral cancer. Ind J Clin Biochem 2010; 25: 250-259. http://dx.doi.org/10.1007/ s12291-010-0060-8

[17] PETERSEN PE. Oral cancer prevention and control-the approach of the World Health Organization. Oral Oncol 2009; 45: 454-460. http://dx.doi.org/10.1016/j.oraloncology.2008.05.02

[18] EDGE SB, BYRD DR, COMPTON CC, FRITZ AG, GREENE FL et al. Part II Head and neck. In: Cancer staging handbook. American Joint Committee on Cancer 7th Edition, Chicago: Springer, 2010: 39-125.

[19] LOWRY OH, ROSEBROUGH NJ, FARR AL, RANDALL RJ. Protein measurement with Folin phenol ragent. J Biol Chem 1951; 193: 265-275.

[20] HEUSSEN C, DOWDLE EB. Elec $\neg$ trophoretic analysis of plasminogen activators in polyacrylamide gels containing sodium dodecyl sulfate and copolymerized substrates. Anal. Biochem 1980; 102: 196-202. http://dx.doi.org/10.1016/00032697(80)90338-3

[21] WOESSNER JF JR. Quantification of matrix metalloproteinases in tissue samples. Methods Enzymol 1995; 248: 510-528. http://dx.doi.org/10.1016/0076-6879(95)48033-1

[22] DIKSHIT R, GUPTA PC, RAMASUNDARAHETTIGE C, GAJALAKSHMI V, ALEKSANDROWICZ L et al. Million Death Study Collaborators: Cancer mortality in India: a nationally representative survey. Lancet 2012; 379: 1807-1816. http://dx.doi.org/10.1016/S0140-6736(12)60358-4

[23] COELHO KR. Challenges of the Oral Cancer Burden in India. J Cancer Epidemiol 2012; 1-17.

[24] RAY JG, GANGULY M, RAO BHS, MUKHERJEE S, MAHATO B et al. Clinico-epidemiological profile of oral potentially malignant and malignant conditions among areca nut, tobacco and alcohol users in Eastern India: A hospital based study. J Oral Maxillofac Pathol 2013; 17: 45-50. http:// dx.doi.org/10.4103/0973-029X.110720

[25] STETLER-STEVENSON WG, YU AE. Proteases in invasion: matrix metalloproteinases. Semin Cancer Biol 2001; 11: 143-152. http://dx.doi.org/10.1006/scbi.2000.0365

[26] HIBBS MS, HOIDAL JR, KANG AH. Expression of a metalloproteinase that degrades native type $\mathrm{V}$ collagen and denatured collagens by cultured human alveolar macrophages. J Clin Invest 1987; 80: 1644-1650. http://dx.doi.org/10.1172/ JCI113253

[27] LUIZON MR, DE ALMEIDA BELO V. Matrix metalloproteinase (MMP)-2 and MMP-9 polymorphisms and haplotypes as disease biomarkers. Biomarkers 2012; 17: 286-288. http:// dx.doi.org/10.3109/1354750X.2012.657685

[28] CHAUDHURY AK, SINGH M, BHARTI AC, ASOTRA K, SUNDARAM S et al. Genetic polymorphisms of matrix met- alloproteinases and their inhibitors in potentially malignant and malignant lesions of head and neck. J Biomed Sc 2010; 17: 10. http://dx.doi.org/10.1186/1423-0127-17-10

[29] NAKAMURA H, FUJII Y, OHUCHI E, YAMAMOTO E, OKADA Y. Activation of the precursor of human stromelysin 2 and its interactions with other matrix metalloproteinases. Eur J Biochem 1998; 253: 672-675. http://dx.doi.org/10.1046/ j.1432-1327.1998.2530067.x

[30] HAZMI A, THOMAS GJ, SPEIGHT PM, WHAWEL SA. The $120 \mathrm{kDa}$ cell binding fragment of fibronectin up regulates migration of $\alpha v \beta 6$-expressing cells by increasing matrix metalloproteinase-2 and -9 secretion. Eur J Oral Sci 2007; 115: 454-458. http://dx.doi.org/10.1111/j.1600-0722.2007.00481. $\underline{\mathrm{X}}$

[31] CHEN HC, APPEDDU PA, ISODA H, GUAN JL. Phosphorylation of tyrosine 397 in focal adhesion kinase is required for binding phosphatidylinositol 3-kinase. J Biol Chem 1996; 271: 26329-26334. http://dx.doi.org/10.1074/jbc.271.42.26329

[32] HAN S, SIDELL N, ROSER-PAGE S, ROMAN J. Fibronectin stimulates human lung carcinoma cell growth by inducing cyclooxygenase-2 (COX-2) expression. Int J Cancer 2004; 111: 322-331. http://dx.doi.org/10.1002/ijc.20281

[33] CHAO X, ZAO J, XIAO-YI G, LI-JUN M, TAO S. Blocking of PI3K/AKT induces apoptosis by its effect on NF-kappaB activity in gastric carcinoma cell line SGC7901. Biomed Pharmacother 2010; 64: 600-604. http://dx.doi.org/10.1016/ j.biopha.2010.08.008

[34] ESPARZA J, VILARDELL C, CALVO J, JUAN M, VIVES J et al. Fibronectin upregulates gelatinase B (MMP-9) and induces coordinated expression of gelatinase A (MMP-2) and its activator MT1-MMP (MMP-14) by human T lymphocyte cell lines. A process repressed through RAS/MAP kinase signaling pathways. Blood 1999; 94: 2754-2766.

[35] XU H, XU Y, ZHANG W, SHEN L, YANG L et al. Aquaporin-3 positively regulates matrix metalloproteinases via PI3K/AKT signal pathway in human gastric carcinoma SGC7901 cells. J Exp Clin Cancer Res 2011; 30: 86. http://dx.doi.org/10.1186/ 1756-9966-30-86

[36] GHOSH S, BASU M, ROY SSL. ETS-1 Protein Regulates Vascular Endothelial Growth Factor-induced Matrix Metalloproteinase-9 and Matrix Metalloproteinase-13 Expression in Human Ovarian Carcinoma Cell Line SKOV-3. J Biol Chem 2012; 18: 15001-15015. http://dx.doi.org/10.1074/jbc. M111.284034

[37] WU H, YANG L, LIAO D, CHEN Y, WANG W et al. Podocalyxin regulates astrocytoma cell invasion and survival against temozolomide. Ex Therap Med 2013; 5: 1025-1029.

[38] VERSTAPPEN J, VON DEN HOFF JW. Tissue Inhibitors of Metalloproteinases (TIMPs): Their Biological Functions and Involvement in Oral Disease. J Dent Res 2006; 85: 1074-1084. http://dx.doi.org/10.1177/154405910608501202

[39] WARD RV, HEMBRY RM, REYNOLDS JJ, MURPHY G. The purification of tissue inhibitor of metalloproteinases-2 from its $72 \mathrm{kDa}$ progelatinase complex. Demonstration of the biochemical similarities of tissue inhibitor of metalloproteinases-2 and tissue inhibitor of metalloproteinases-1. Biochem J 1991; 278: 179-187. 